\title{
Transformation and African migrants: The conflicting worlds of cultural beliefs and marriage issues in No longer at ease andChairman of fools
}

\author{
J. N. Indongo, T. C. Smit \\ University of Namibia, Windhoek, Namibia \\ nelagosheeli@gmail.com \\ University of Namibia, Windhoek, Namibia \\ tcsmit@unam.na
}

\begin{abstract}
Human beings can be moulded by the geographical location in which they find themselves. Many Africans, just like Obi in No longer at ease and Farai in Chairman of fools, travel overseas for education and better paid jobs. During vacations or upon completion of their studies most of these Africans return home to their families in Africa. Some of them encounter conflicts because they expect the people who remained in Africa to behave in the same way as they behaved in the past. The returnees do not consider that even they themselves have changed and life is not stagnant. Paradoxically, the migrants also seem to expect African societies to operate in exactly the same way as those societies they have been immersed in while overseas. This article presents an investigation of the way African authors depict characters migrating between two continents and how these characters are affected by the conflicting geographical, as well as metaphysical, worlds they live in. In the two novels studied it appears that the differences in cultural beliefs and marriage issues are responsible for the inner and interpersonal conflicts that the main characters experience.
\end{abstract}

\section{Indexing terms/Keywords}

Transformation; migration; metaphysical world; Hybridity; Transnationalism; lobola; bride price

\section{Academic Discipline And Sub-Disciplines}

Humanities: languages

\section{SUBJECT CLASSIFICATION}

Literature

\section{TYPE (METHOD/APPROACH)}

Qualitative case study

\section{Council for Innovative Research}

Peer Review Research Publishing System

Journal: Journals of Advances in Linguistics

Vol.6, No 1

editor@cirjal.com

www.cirjal.com, www.cirworld.com 


\section{INTRODUCTION}

Human beings can be moulded by the geographical location in which they find themselves. Many migrant Africans, during their vacations from work or upon the completion of their studies, return home to their families in Africa. Upon their return the returnees often encounter inner and interpersonal conflicts due to a variety of reasons. These conflicts mainly appear to stem from their expectations that those who remained in Africa should behave in the same manner as they had behaved before the migrants left their home countries. These returning migrants often fail to consider that even they themselves have changed, and that life is not stagnant. In addition, they also seem to expect African societies to operate in the same way as those societies they were immersed in while overseas. Therefore, it appears that, upon their return, many migrants struggle with re-adaptation into their native societies. According to Matthias and Pierre (2008), even when migrants prepare for their return to their home countries, they are not, "immune to the process of re-adaptation in the home country and a personal reflective experience of belongingness" (p. 102).

Abdile and Pirkkalainen (2011) conducted a study in which they examined the relationship between Somali migrants, who returned to their home country, and their local communities. The authors found that the outcome or consequences of migrants returning were very difficult to assess; hence, little was known about the anticipated conditions awaiting them (Abdile \& Pirkkalainen, 2011). The potential challenges, however, include conflict experienced with their community when they return temporarily or permanently, as well as how they are perceived by this community.

The two protagonists in the novels scrutinised, Obi in No longer at ease (1963) written by Chinua Achebe and Farai in Chairman of fools (2005) written by Shimmer Chinodya, had different reasons for migrating from their native countries and staying away for extended periods of time. Obi was sent to England to study for four years with money raised by the Umofia Progressive. When he returned to Nigeria, he was no longer at ease with his Nigerian people because, as Gillard (2009) says, "Obi finds himself between the Nigerian and European world" (para. 8). On the other hand, Farai Chari had been teaching in the USA for some years. When he returned to Zimbabwe, he encountered serious misunderstandings with almost everyone in the community, including his wife.

\section{Theoretical framework and literature reviewed}

According to Bhabha (1994), the hybridity theory deals with integrating two worlds and operating within a third space; for example, Obi and Farai's conflicts are a result of being in two different geographical and metaphysical worlds. The challenges experienced by these characters lie in integrating these two worlds to operate within the third space, which is life at home after returning from overseas. Dia (2014, p. 33) indicates that "hybridity has been defined in different ways by various scholars, but to put it in simple words, hybridity is the fact of being cross-bred or living in-between-two cultures". Bhabha (1994) suggests finding a third space which is in-between-two cultures to avoid conflicting values and morals.

According to Dia (2014, p. 33), the concept of a third space is a place of enunciation to experience multiculturalism through the concept of hybridity. For Bhabha (1994, p. 60) the "third space of enunciation" is situated between the "l" and "you". It facilitates the integration of each culture in the universal civilisation; therefore, hybridity is not only biological, but also cultural. The third space provides people from different cultures a space where they can combine their culture of origin with the one acquired in the process of hybridisation. The hybridity theory has been deliberated by many scholars. Young (1995) believes that the hybridity theory provides a means to assist in the reduction of both psychological and physical conflicts stemming from the demands of the specific world where the migrant finds him- or herself at a specific time.

Yazdiha (2010) mentions that "hybrid [sic] can deconstruct boundaries within race, language and nation". He further suggests that "hybridity has the ability to empower marginalised collectives and deconstruct bounded labels, which are used in the service of subordinations" (p. 36). With this in mind, the hybridity theory was employed to deconstruct the rationale behind Obi's and Farai's inner and interpersonal conflicts.

Furthermore, the theory of transnationalism was developed in the 1990s by pioneers such as Linda Basch, Nina Glick Schiller and Christina Szanton Blanc because there was a need for a new paradigm to address migration studies (Bekerman \& Geisen, 2012). According to Schiller (1992), cited in Bekerman and Geisen (2012, p. 23), transnationalism is defined as, "... the process by which immigrants and former immigrants build social fields that link together their country of origin and their country of settlement". Furthermore, Bekerman and Geisen (2012) mention that transnationalism looks at migration as a context. In Bekerman and Giessen's words, "[m]igration as a context looks at the effects of migration in a given social context and how it becomes the new centre of life for immigrants, as well as the consequences of emigration on the social context which the migrant has left" (2012, p. 23). Transnationalism assist in the focus on Obi and Farai as characters that were involved in cross-border migration as it enables a review of the aftermath of migration on their social lives in their native communities. Jakubowicz (2012, p. 2) states that "the theoretical concept of transnationalism, ..., deals with the question of "how". The emphasis is not on migration itself, but rather on the crossborder actions of migrants and their descendants.

Migration and transnationalism: Opportunities and challenges $(2010$, p. 1) states that "[w]ith respect to migration, being connected to several places at once - or 'being neither here nor there' - has long been a defining feature of the experience of being a migrant." Migration and transnationalism: Opportunities and challenges (2010) further explains that the transnationalism theory also takes into account those who remain behind, while their loved ones migrate abroad. Consequently, those who remain behind are affected by migration in the same way that it affects the migrants. When dealing with the transnationalism theory, it is vital to consider families of migrants who remain in their country of origin. In other words, in order for one to achieve a clearer picture of cross-border migration and how it affects people, one needs 
to include all the stakeholders, not only those who migrated. This approach can assist in further revealing Obi and Farai's conflicts.

\section{Traditional beliefs}

Lalonde (n.d, p. 58) defines culture "as the norms and standards of a group that will delineate the appropriateness of behaviour". The author's definition implies that culture is what defines the types of behaviours that are appropriate in any given setting. He further uses the concept of bicultural people to refer to "... individuals with psychological access to two sets of cultural norms that may be tied to geography, ethnicity and/or religion" (Lalonde, n.d, p. 58). Obi and Farai are bicultural as they have two sets of cultures which they have acquired in the two different geographical worlds in which they live. The issue of cultural differences of bicultural people is relevant as cultural differences were investigated to determine whether they have contributed to the conflicts experienced by Obi and Farai.

In Igboland, a society based in Nigeria, a child relies on the whole society for moral teaching, not only on his or her parents. The community is responsible for ensuring that every child is raised in line with the culture and values of the society. If a person whom the society has brought up according to their expectations lives in two geographical worlds through migration and adopts values, standards and interests of the second world that are contrary to the those of the society that has raised him or her, then tension may arise. This occurred when Obi came back to Igboland and occasionally behaved like a westerner in Africa. The Nigerian society disapproves of such western behaviour and in the end conflict ensues between the two parties involved.

\section{Issues and prejudices regarding marriage}

Lalonde (n.d) explains that cultural norms play a role in how one selects a life partner and how to look for a potential partner in marriage. In western culture, marriage is viewed as a union between two people. Although the family needs to be informed for approval, young adults are expected to find their own partners without their parents' involvement and assistance. Marriages are seen as a result of the couple's romantic love.

In African culture, marriages are the alliance between two families. Parents need to become involved when young adults are selecting life partners. Africans who have elements of both western and African culture may find themselves in conflict with their families when it comes to the selection of their life partners as their families may not be in agreement with the partners they want to marry. Families want to ensure that the person who marries their son or daughter, is the type of person that they would prefer to connect to. This is due to the fact that in African culture and tradition, marriage connects families. Living in two different geographical worlds has affected Obi's ideas concerning the choice of a life partner, and these aspects have contributed to his inner and interpersonal conflict.

Dion and Dion (1993) explain that in the western world, marriage is a result of a couple's emotional feelings or romantic love. Thus, when it comes to whom one should marry in a western setting, the choice is purely based on the love between the two couples. One chooses whom to marry without considering the family history or connections attached to their partner's family. An African individual who has lived in the western world and who prefers the notion of choosing a marriage partner, may decide to choose a life partner based on love, and ignore prejudices attached to certain families. In the end, such a choice, contradictory to tradition, may result in tension. On the other hand, a western person who grew up in an African environment may expect his or her parents to choose a marriage partner for him or her, if he or she views this as the best practice. Obi's parents believe they have the right to decide whom he should not marry. Obi, however, cannot understand this as he has also been influenced by the second world (England) where he lived. In England a man has the right to choose his or her own partner and disregard society's prejudices against certain people or tribes.

\section{Methodology}

In order to analyse the inner and interpersonal conflicts of Obi in No longer at ease and Farai in Chairman of fools a qualitative, desk top study was undertaken. Apart from the two novels as primary sources, secondary sources and any other elaborative documents on conflict that could be related to and shed light on Obi and Farai's conflicts were scrutinised. The research population was African literature written in English by African authors about the conflicts of living in two geographical and metaphysical worlds while having to operate in a third space. Purposive sampling was employed as the two novels, No Longer at ease and Chairman of fools have a similar theme, namely the inner and interpersonal conflicts of the protagonists. The two novels were read in-depth. Special focus was paid to Obi and Farai's inner and interpersonal conflicts and how they integrated the two different geographical and metaphysical worlds into the third space after returning home (Bhabha, 1994). Secondary sources that contributed to the discussions regarding Obi and Farai's conflicts were scrutinised. Conclusions on Obi and Farai's conflicts were made based on the information from the two novels and secondary sources.

The content analysis method was used to analyse the data that were collected by reading the two novels, No Longer at ease and Chairman of fools, and studying the two characters, Obi and Farai. By implication, the researcher also employed discourse analysis to shed more light on these conflicts. These emerging conflicts were analysed in relation to the hybridity theory and the theory of transnationalism. The researcher avoided personal biases in the analysis by remaining objective when analysing Obi and Farai's conflicts.

\section{Findings}

The two differing cultures and traditions of the two geographical worlds, the Nigerian world and British world, in which Obi lives, as well as his metaphysical world affect the way Obi looks at life upon his return to Nigeria. This is illustrated when 
Obi is waiting for Clara at the open market; he mentions to Clara that "I can't understand why you choose your dressmaker from the slums." Clara did not reply. Instead she started humming "Chesarasara" (p. 13), indicating that she does not find it odd to buy from a shop in the slums like most Nigerian women have always been doing. The fact that Obi does not understand why Clara has to buy her dress from the slums and not from a more reputable dressmaker's shop is an indication that Obi does not understand the Nigeria culture anymore; it was prevalent for Nigerian women to buy from the slum, from their own people. Achebe, purposefully, mentions that Clara did not reply to Obi's qualms about buying in the slums. Instead, Clara uses some local phrase, to tell the readers about the contrast between the local tradition and the new changing world, characterised by Obi's metaphysical world. Obi's objection can, therefore, be attributed to living in two geographical worlds, as in the 'British' world, people buy only from decent shops and not from shops in the slums like in Nigeria. Furthermore, it shows that even if Obi is currently physically in a traditional society, metaphysically he still relates to his adopted British world where people buy from decent shops.

Achebe mentions that at the welcoming meeting of Obi in Lagos "[e]verybody was properly dressed in agbaba or European suits except the quest of honour, who appeared in his shirtsleeves because of the heat" (p. 25). From the statement quoted it is clear that it is a Nigerian culture for people to put on agbaba or a suit whenever they are attending an important meeting. The fact that Obi does not wear the required attire can also be attributed to the English culture of dressing according to the weather. The English world has influenced Obi to dress for comfort even though that would be regarded as improper in Nigeria. Achebe uses the phrase "properly dressed" (p. 25) ironically to make the reader question which of the characters is actually dressed properly: Obi or the Umuofians, given the fact that it is hot.

Furthermore, living in two worlds has changed Obi's perceptions regarding the paying of a bride-price, which is also known as lobola in Africa. Obi is an African man and any African person is supposed to understand lobola, but Obi seems not to understand this and does not agree with the system of lobola. The conversation between Obi and Joseph shows this discrepancy between Obi's Nigerian culture and the culture of his adopted country, England:

'Didn't I tell you I was getting married?'

'So what?'

'When you have paid a hundred and thirty pounds bride-price and you are only a second class clerk, you findyou haven't got any more to spare on other women.

'You mean you paid a hundred and thirty? What about the bride-price law?'

'It pushed up the price, that's all'.

'... I am not paying five hundred pounds for a wife. I shall not even pay one hundred, not even fifty.'

'You are not serious,' said Joseph. 'Unless you are going to be a Reverend Father' (p. 33).

Obi's stance against the custom of lobola can also be attributed to his having lived in a second geographical world, the English world, where people do not pay lobola. If Obi would have lived in the Nigerian world only, he would have understood and accepted the bride-price like all other Nigerians, as represented by Joseph in this case. It can thus be concluded that Obi's opposition to the bride-price is an indication that metaphysically he is living in a world different from the traditional African world. Achebe uses Obi as a symbol to suggest that the new generation in a new and changing Africa will not be prepared to adhere to some of the outdated or irrational cultural and traditional customs, such as paying a bride-price.

Likewise, it appears as if Farai is not in agreement with some of the cultural practices of the Zimbabwean world. The night Farai goes to the traditional dance with Fatima and Enesti, Farai runs away as he is not willing to participate in the dance, but would rather watch others dance. This is regardless of the fact that all the participants were male. Chinodya illustrates Farai's unwillingness to participate in traditional Zimbabwean dancing:

The dancer pauses, then struts around searching for the next victims ... Farai feels chosen, trapped and has a weird foreboding of things to come ... Farai's quart tips over into dusty, thirsty earth like an offering to unknown spirits and he freezes, cowering in the space between the two stilts. He sees the dancer sway above him and the mask staring angrily at him. He plunges into the crowd, ploughing up a hurried exit with his arms. Outside in the gathering dusk silhouettes scatter and he scrambles for his car, leaps in and starts the engine. (p. 9)

This traditional dance represents the Zimbabwean culture and traditions. The fact that Farai chooses to run away from the traditional dance means that Farai is running away from his own heritage, culture and tradition. Therefore, Chinodya is suggesting that Farai lives in a different metaphysical world from those of his people, when he returns to Zimbabwe. Farai's experiencing conflict about the traditional dance symbolises that he is in conflict with his African traditions and customs.

In African, many people relate their misfortune to superstitious reasons; for example, when a person dies unexpectedly, they may conclude that witchcraft is the cause of death. In Chairman of fools (2006), when Farai is in hospital, Mr Pimples warns Farai not to consume milk, as Mr Pimples was informed by one of the traditional healers that milk was also a source of problems for people of his family. Mr Pimples claims that he is part of Farai's family. Regardless of Mr Pimples' words to Farai not to consume milk, it is stated that "[a]t breakfast he [Farai] again has two mugs of tea with milk and several chunks of bread. Mr Pimples glares at him with displeasure as he sips his tea" (p. 121). In this case Mr Pimples represents typical Zimbabwean (African) men who have lived only in Zimbabwe. Chinodya presents Farai's rejection of 
Mr Pimples' instruction as a suggestion that even when Farai is geographically living in Zimbabwe, metaphysically he belongs to a different world as he refuses to be manipulated by the superstitions of the Zimbabwean world.

It is vital for married couples to live in the same metaphysical world even if they do not always share the same geographical world. In Chairman of fools (2005) one of the causes of Farai's conflict is the fact that he is living in a different world to that of his wife, Veronica. Farai still lives in a traditional world which is characterised by a chauvinist mentality. This is indicated when Farai tells his wife that "You left me no supper" (p. 2) and again Farai asks Veronica "[w]hat about breakfast" (p. 3) when she is ready to go to church. This is regardless of the fact that Farai has been preparing his meals himself while he was in America. On his return to Zimbabwe he is still demanding that his wife cooks for him because, according to African traditions, particularly in the Zimbabwe he knew prior to his departure, where women always cooked for their husbands; however, things have changed also in Zimbabwe while he was away, as Veronica, in return, instructs him to make his own breakfast. Farai's chauvinist mentality thus shows that living in two geographical worlds actually disadvantages Farai, because he does not know that the situation has changed in Zimbabwe. That is why he still expects his wife to submit to his requests. In the end, it causes conflict with his wife.

Furthermore, Farai needs a wife and this is why he does not divorce Veronica. At the same time, Farai's actions are pushing his wife away from him. Examples of this is his arguments with her (p. 3) and his consuming far too much alcohol, as it is mentioned by the police that he meets at the road block the day his car reeks of alcohol (p. 11). Farai unconsciously has two contradicting desires of wanting company and a loving family but, at the same time, he is unconsciously pushing the wife away from him and this causes him inner conflict.

The Zimbabwean tradition challenges and requires a husband to stay with his family regardless of any misunderstanding. This is indicated by Wilbert, Farai's friend, who advises Farai to stay with his wife and go to church with her sometimes, regardless of the fact that Farai does not like the new church. Furthermore, Fatima advises Farai that "make sure you don't lose her [Veronica, his wife]" (p. 7). Wilbert and Fatima are used as symbols to indicate the society's traditional view on marriage, which Farai seems not to regard as important, because even when his wife leaves him, all he seems to worry about is his children. This is further indicated by the fact that after Farai has found his children, he stops trying to locate his wife. Again, it appears that although Farai is residing geographically in Zimbabwe, metaphysically he lives in a different world with different beliefs to those of the Zimbabwean society.

In Nigeria the society discriminates against the osu people when it comes to marriage. Osu people cannot marry because they are outcasts and the society takes such prejudices seriously. The issue of discrimination against the osu is mentioned in the conversation between Clara and Obi:

'I can't marry you,' she said suddenly as Obi tried to kiss her under the tall mango tree at the edge of the swimming-pool, and exploded into tears.

'I don't understand you, Clara.' And he really didn't. Was this the woman's game to bind him more firmly? But Clara was not like that; she had no coyness in her. Not much, anyway. That was one of the things Obi liked best about her. She had seemed so sure of herself that, unlike other women, she did not consider how quickly or cheaply she was captured. 'Why can't you marry me?' He succeeded in sounding unruffled.

There was a hint of tears in his voice.

'I am an osu,' she wept. Silence. She stopped weeping and quietly disengaged herself from him. Still he said nothing.

'So you see we cannot get married,' she said, quite firmly, almost gaily - a terrible kind of gaiety. Only the tears showed she had wept.

'Nonsense!' said Obi. He shouted it almost... (p. 56).

Although geographically Obi lives in a Nigeria that practises such discrimination, metaphysically he lives in a new changing world where all human beings are equal and treated the same. Obi is not prepared to let Clara go only because she is an osu. Obi's metaphysical world is shaped by the English world because in England people believe in the equality of all people. The author portrays Obi as living in a new world and Clara living in a traditional world where osu people are still being discriminated against. This is indicated by the way Clara seems to admit that osu people are not like other people; hence, the osu do not get married. She, herself declares that she is an osu, therefore, she cannot marry Obi. Achebe uses this scenario of the differences in Obi and Clara's beliefs to show that prejudices in Nigeria against osu people are deeply rooted. This is to the extent that even osu people themselves, like Clara, take those prejudices as real. Achebe further suggests that young people who have experienced the peaceful atmosphere of a society where equality prevails, like Obi experienced in England, strive to change the situation, no matter who deeply rooted it is.

It is very important for partners who are in love to live geographically and metaphysically in the same world to avoid conflicts, like that of Obi and Clara. Achebe, through the character of Obi, is again emphasising that the new generation is prepared to mix the varying aspects of different worlds. This is achieved by doing away with African beliefs that are seen as unacceptable and replacing them with those of the western world. This is indicated by Obi being prepared to marry an osu, regardless of the fact that it is a taboo in the Nigerian society.

Metaphysically, one can see the conflict in Obi who still lives in two different worlds: the world of old traditions, where people believe in getting married first before they live together and the world of acceptance of people regardless of who they are. That is why Obi does not want to cohabit with Clara, but he wants to marry her first, as it has always been done in Nigeria. The other world he lives in is a new, changing world, characterised by modernity, where people do not follow 
prejudices, such as that osu people cannot be married. Furthermore, the education that Obi received in the England has transformed his perception regarding the discrimination and prejudices against osu people. In the conversation between Obi and Joseph about Clara, who is an osu, Obi mentions that

'I am going to marry,' Obi said.

'What!' Joseph sat up in bed.

'I am going to marry her'.

'Look at me,' said Joseph ...

... 'You know book, but this is no matter for book. Do you know what an osu is? But how can you know?

'I know more about it than yourself,' he said, 'and I am going to marry the girl. I wasn't actually seeking your approval (p. $57)$.

Regardless of Joseph's input and advice that Obi should not marry an osu, Obi seems unwilling to change his mind and keeps on repeating the same information that he will marry an osu. Achebe uses the character of Joseph to tell the readers that the discrimination against osu people in marriage is not only among the older generation, but even among the youth themselves, especially those who have only lived in one geographical world. He is also further emphasising the point that those youths who are living in two different worlds and who have received a western education that liberated their minds, are ready to change the situation in Nigeria by going against traditional taboos.

Achebe suggests that the "effect that Obi's mission-house upbringing and European education had made him a stranger in his country - the most painful thing one could say to Obi" (p. 57). In other words, Achebe is blaming Obi's ignorance of osu prejudices on the education that he has received, as well as on the fact that he was raised in the house where missionary Christianity is followed. On the issue of mission-house upbringing, the author seems to contradict the same idea of mission house upbringing, with the conversation between Obi and his father, when they say:

'I said you cannot marry the girl.'

'But why, Father?'

'Why? I shall tell you why. But first tell me this. Did you find out or try to find out anything about this girl?'

'Yes'.

'What did you find out?'

'That they are osu.'

'You mean you tell me that you knew, and you ask why?'

'I don't think it matters. We are Christians.' This had some effect, nothing startling though. Only a little pause and slightly softer tones.

'We are Christians,' he said. 'But that is no reason to marry an osu'. (p. 57)

Obi's father is more Christian than other characters in the book and he teaches Christianity; however, at the same time he is also against Obi wanting to marry Clara who is an osu; this is ironic, because to God all people are equal regardless of their background. Obi tries to convey the idea to his father that religious people are not supposed to discriminate against others, by quoting bible verses to convince him. Achebe uses irony to indicate that prejudices against osu people in marriage are also deeply rooted in the Nigerian world even among the Christians. Achebe is further suggesting that it is only those who have lived in a second geographical world and have experienced the cultures and practices of the western world who are willing and ready to change their views and eradicate unfair practices such as this marriage taboo.

This is, however, not the case in the Nigerian world, as relatives have the right to object to whomever they do not want their sons or daughters to be married to. The contrasting beliefs on marriage in the two different geographical worlds put Obi in conflict, especially with his mother who could not agree with his choice; hence she threatens him that

'If you want to marry this girl, you must wait until I am no more. If God hears my prayers, you will not wait long ...

'But if you do the thing while I am alive, you will have my blood on your head, because I shall kill myself.' She sank down completely exhausted. (p. 108)

The words uttered by Obi's mother indicate that even if Obi wants to choose a person to marry, according to the norm in England, while he is Nigeria, the society will not accept his way. The society keeps on defending its traditional belief that a Nigerian child cannot marry an osu. The fact that Obi's mother uses her death as a threat to stop Obi from marrying Clara indicates that the Nigerian society will do anything to stop such an 'abomination'. Therefore, it will not be easy to do away with traditional Nigerian beliefs. 


\section{Discussion}

There are both similarities and differences in terms of Obi and Farai's conflicts as portrayed in No longer at ease (1963) and Chairman of fools (2005). Obi's lengthy stay in England has caused him various conflicts when he returns to Nigeria. Kangira (2012) states that in the four years that Obi was in England he forgot how to behave like a Nigerian, as well as how to live as a Nigerian man in Nigeria; he now behaves like a foreigner when he returns. It thus appears that Obi has been transformed by the English world where he lived and that he has forgotten what is expected from him by the Nigerian society.

In Chairman of fools (2006) the author portrays Farai as the victim of a society that has undergone much transformation while he was away. Farai chooses to retain certain chauvinistic customs of Zimbabwean men while he was abroad, and he returns with the same mind-set that he had before he left Zimbabwe. However, while he was away, the society changed; thus, being a chauvinist is a thing of the past in Zimbabwe. This societal transformation causes Farai to experience numerous conflicts, because many people condemn his behaviour that still relates to previous discrimination against women in Zimbabwe.

Farai's behaviour can be linked to the transnationalist theory (1990) as it is not always a good idea for migrants to retain certain customs of their traditional societies while they are abroad; the society may transform itself in different aspects over time. Therefore, the returning migrants may still hold on to those old customs of their society, which may be considered out-dated and strange in the transformed society; this conflict has been experienced by Farai.

It appears that former migrants can blend well into the lifestyles that they find in their native countries when they return, if they have kept close connections through communicating with their family and friends in their native countries while they were away in their newly-adopted geographical worlds. They can be informed about current shifts, such as lifestyle changes, in their home countries. For example, Obi is supposed to accept the traditional lifestyle of corruption, prejudice and bride-price that he finds in Nigeria, while Farai is supposed to accept the new lifestyle as demonstrated by the Pentecostal church and a modern way of life where equality prevails. This is exactly what Bhabha (1994) is advocating in the hybridity theory that people need to create a third space that facilitates the integration of different lifestyles. The third space could have prevented Obi and Farai's conflicts if they could successfully integrate their own lifestyles and those of their society, both traditional and modern. This would have resulted in the peaceful living together of everybody.

Pourjafari (2014) states that literature represents what is happening in reality; through fictional characters and scenarios such as that of Obi and Farai authors describe the interpersonal and inner conflicts resulting from migration. In this study it has become clear that both characters did not prepare themselves mentally for any changes they may encounter when they return from overseas; thus they experience many situations which result in many inner and interpersonal conflicts for both characters.

Both authors, Chinua Achebe and Shimmer Chinodya, are suggesting, through their novels, that migration is a lifealtering experience as neither of the worlds the migrants live in is stagnant. Hence, returning migrants need to prepare themselves mentally for any changes or form of challenges they may find in their society, as well as in themselves in order avoid unnecessary conflict.

\section{REFERENCES}

[1] Achebe, C. 1963. No longer at ease. London,UK: Penguin books.

[2] Abdile, M., \& Pirkkalainen, P. 2011. Homeland perception and recognition of the diaspora engagement: The case of the Somali diaspora. Nordic Journal of African Studies, 1(20), 48 - 70.

[3] Bhabha, H. K. 1994. The location of culture. New York, NY: Routledge.

[4] Bhabha, H. n.d. Cultural policies as catalysis of creativity.

Retrieved from http://www.unesco.org/culture/aic/echoingvoices/homi-k-Bhabha.php

[5] Bekerman, Z., \& Geisen, T. 2012. International handbook of migration, minorities and education: Understanding cultural and social differences in processes of learning. New York, NY: Springer.

[6] Bui, Y. N. 2014. How to write a master's thesis. ( $2^{\text {nd }}$ ed.). London, UK: SAGE Publication.

[7] Chinodya, S. 2005. Chairman of fools. Harare, Zimbabwe: Weaver Press.

[8] Dia, A. A. 2014. Diversity vs difference: A critical analysis of hybridity and cultural identity crisis in the novel of Cheikh Hamidou Kane and Chinua Achebe. International Journal of English Language, 2(1), 31- 44. Retrieved from http://www.eltsjournal.org

[9] Dion K. K., \& Dion K. L. 1993. Individualistic and collectivistic perspectives on gender and the cultural context of love and intimacy. Journal of Language and Social Psychology, 49(3), 53-69.

[10] Gillard, G. n.d. Chapter 8: Interpretive abstractions and worldview. Retrieved from http://www.garrygillard.net/writing/AfriNarr/ch8.htm/

[11] Grinberg, L., Grinberg, R, \& Kernberg, F. 1989. Psychoanalytic perspectives on migration and exile. London, UK: Karnac. 
[12] Jakubowics, L . 2012. Transnationalism-migration-intergration: Migration and nation states in the modern world order through the prism of the concept of transnationalism. Journal for Police Science and Practices, 2(1), 4 -18.

[13] Kangira, J. 2012. An overview of African literature. Windhoek, Namibia: UNAM Centre for External Studies.

[14] Lalonde, R.N. n.d. When might the two cultural worlds of second generation bicultural collide? Retrieved from http://pgs-can-diversity-spring08_cultural_world_epdf

[15] Matthias, K., \& Pierre, J. C. 2008. The conditions of modern return migrants. International Journal on Multicultural Society, 1(1), 95 - 279.

[16] Migration and Transnationalism: Opportunities and Challenges 2010. Retrieved from http://www.iom.int/jahia/.../workshops/migration.../background_paper_en.pdf

[17] Otjinmah, U. n.d. Chinua Achebe: New perspectives. Lagos: Spectrum Books Limited.

[18] Pataki, E. n.d. Caught between two worlds.

Retrieved from http://www.theroundtable.ro/.../eva pataki caught between two worlds.doc

[19] Pourjafari, F., \& Vahidpour, A. 2014. Migration literature: A theoretical perspectives. The Dawn Journal, 3(1), 679-692.

[20] Smith, L., Levitt., P. \& Jaworsky, N. 2007. Transnational migration studies: Pat developments and future trends. Retrieved from http://www.ssrc.org/publications/... /3E9F61AB-3E55-DE11

[20] Yazdiha, H. 2010. Conceptualizing hybridity: Deconstructing boundaries through the hybrid. Formations, 1(1), 3136. Retrieved from http://www.jstor.org

[21] Young, R. 1995. Colonial desire: Hybridity in theory, culture and race. London, UK: Routledge.

\section{Authors' biography with Photo}

Julia N. Indongo is Master's In English Studies student who gradiuated in 2015. Dr Talita C. Smit was her supervisor at the University of Namibia, Faculty of Humanities and Social Sciences, Department of Language and Literature Studies, English Section.

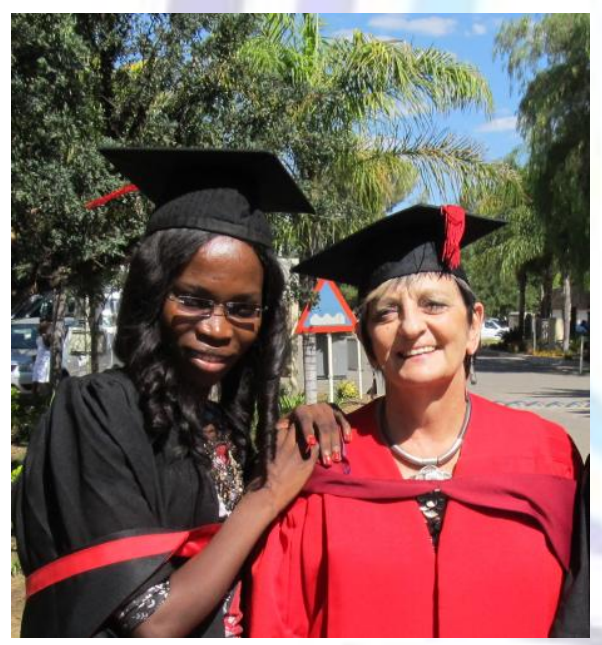

